ISSN 1991-8631

Original Paper

http://indexmedicus.afro.who.int

\title{
Limestone quarrying : the impact on the vegetation and landform of sagamu cement factory site, Sagamu, Southwestern Nigeria
}

\author{
S. O. OKE*, and G. A.O. IBHANESEBHOR \\ Department of Botany, Obafemi Awolowo University, Ile-Ife,Nigeria. \\ *Corresponding author, E-mail: soke@oauife.edu.ng ; +23408035803308
}

\begin{abstract}
Species composition of the vegetation of several sites (worked; unworked; spoil heap in the quarry and its environs) in a cement manufacturing town, Sagamu, Southwestern Nigeria, was studied. The aim was to document the plant species compostition (biodiversity) of the quarry sites and its environs, which will provide baseline data for assessing the impact of limestone quarrying on the vegetation of the area. Two sampled plots, each measuring $25 \mathrm{~m} \times 25 \mathrm{~m}$, were studied in each site by complete enumeration of all the woody species and their girth measured at breast height. Limestone excavation in the area has altered the landform by creating new and varied habitats, namely, ponds and spoils heaps, which were not originally in the area. The spoil heaps have provided a haven for Pinus caribaea, a rare species of the vegetation of the area while Typha australis and fern are peculiar to the ponds and their banks. The original vegetation of the area has been greatly disturbed by agricultural activities and limestone quarrying. The present vegetation is a regrowth as evidenced by the small girth sizes of the woody species. Three distinct vegetation types, namely, gallery forest along water course, spoil heap vegetation dominated by Pinus caribaea and Terminalia catapa, and lowland secondary grasslsand vegetation dominated by Anthocleista vogelli, Alchornea spp and Spondia mombin. The spoil heap vegetation has fewer woody species but higher density than lowland secondary grassland vegetation with several species. The dominant grass species across all the sites were Andropogon tectorum, Panicum maximum, Penisetum purpureum and Sorghum bicor, and forb species were Aeschynomene cristata, Chromolaena odorata and Ipomea spp.

(C) 2013 International Formulae Group. All rights reserved.
\end{abstract}

Keywords: Environment, excavation, quarrying, biodiversity, vegetation, species.

\section{INTRODUCTION}

Mineral exploration directly affects plant biodiversity through both physical and chemical modification of the environment, and indirectly in a variety of ways (Ratcliffe, 1974). The most obvious impact of mineral exploitation is that of physical change to the land surface, with its cover of soil and vegetation. Through this process, habitats can be altered or destroyed. The quarrying sector's primary impact on biodiversity is through the removal of surface features during the extraction of minerals (BBRC, 2012). One of the biggest negative impacts of quarrying on the environment is the damage to plant biodiversity (Sustainable floor, 2009). Quarrying carries the potential of destroying habitats and the species they support. 
Secondary effects of the quarrying process, such as noise, dust, pollution and waste removal can also impinge on plants and animals population. Usually these effects include a combination of changing land forms and disturbance, for instance through sedimentation which may arise through excavation and disturbance to land or water through the activities themselves. (BBRC, 2012). Disturbance to an ecosystem means any discrete event that disrupts the ecosystem, community or population structure, or the physical environment (Pickett and White, 1985). Species composition, community dynamics and human welfare services of ecosystems become adversely affected by disturbances of both natural and anthropogenic origin (Sousa, 1984). Habitat destruction is the leading cause of species extinction and biodiversity loss in natural ecosystems (Pimm and Raven, 2000; Koh et al., 2004).

The nature of the extraction is inherently damaging to the environment not just because of the production process but also because the end products serve to increase greenhouse gas emissions, waste energy, and discourage recycling of resources. Vegetation removal also accounts for part of the world's greenhouse gas emissions. Prevention of natural forest from being removed, is protecting carbon stores vital in the fight against climate change. In addition, promotion of the regeneration of degraded forest leads to active uptake of carbon.

In reality, many quarries provide wild life havens in areas where biodiversity is otherwise limited by other forms of land-use such as farming. Through careful management, quarries can significantly enhance the biodiversity of an area and provide much needed habitats such as small cliffs, arid environments and ponds.These areas can encourage certain species to become established. Quarrying provides a unique opportunity to enhance the nature conservation.

Many quarries are also important reservoirs of biodiversity. Many quarries aim to increase biodiversity and an index to measure the biodiversity in these quarries is important. Ecosystems can contribute to mitigation of climate change in the tropics. To preserve the biodiversity and carbon values, the forest can be managed for ecosystem restoration by replanting with native trees. Restoration is a major opportunity for the industry to enhance biodiversity.

Understanding of forest processes is necessary for assessment of impacts, the amelioration of effects of disturbance, optimisation of productivity and rehabilitation of ecosystem (Congdon and Herbohn, 1993). In 1976, the West African Portland Cement Company, Sagamu (WAPCO) was incorporated in Nigeria and started commercial production of cement in 1978. In dry and rainy season 2009, field trips were made to the factory site to study the vegetation of the area and study sites were established within and outside the factory with a view to assessing the impact of cement manufacturing on the vegetation of the area. This paper reports the existing plant biodiversity of the area.

\section{MATERIALS AND METHODS}

\section{Study area}

The study area is a cement-producing town of Sagamu (Latitude $06^{0} \quad 48^{\prime} \mathrm{N}$ Longitude $003^{0} 37^{\prime} \mathrm{E}$ ) in Sagamu local Government area in Ogun State. It is in the derived Savanna zone of Nigeria (Keay, 1959). White (1983) has described the vegetation as mosaic of lowland rain-forest and secondary grassland of Guinea-Congolian type. The soil developed over sedimentary rocks and is a well-weathered well drained 
soil with deep profile.The rainy season lasts from April to November while the dry season prevails for the remaining months. The wettest month is September and approximately $90 \%$ of the rainfall occurs between April and October.The temperature ranges from mean minimum of $21.1^{\circ} \mathrm{C}$ to mean maximum of $31.7^{\circ} \mathrm{C}$.

\section{Sampling procedure}

The vegetation of three sites in the quarry area (worked; unworked; spoil heap) within the factory premises and another three sites outside the factory premises (Sotubo, Atoyo and Senior Staff Quarters) were sampled. Two sampled plots, each measuring $25 \mathrm{~m} \mathrm{x} 25 \mathrm{~m}$, were studied in each site.Worked area refers to area where limestone excavation has been carried out, while in unworked area there is no excavation. The sample plots were chosen systematically based on the sites where excavation has been carried out or not been carried out within the factory site. The same procedure was adopted in sites outside factory but here the choice of sample plots was based on sites where there was no evidence of recent farming.

In each site and within each plot, all the woody plants were enumerated and identified to species level. Their girths were measured at breast height. All herbaceous species within the sample plots were identified and their abundance visually estimated and classified as abundant, common or scarce. Species nomenclature is according to Hutchinson and Dalziel (1972). Descriptive statistics involving the use of mean, standard deviation and standard error was used to analyse the data.

\section{RESULTS}

\section{Species composition of the vegetation}

A total number of 141 plant species belonging to 121 genera, and 49 families were recorded from all the sites (Spoil heap, worked, unworked and outside the factory premises) of study area.

\section{Spoil heap sites}

The older spoil heaps were dominated by Pinus caribaea and Terminalia catapa. Other common woody species are Albizia zygia, Albizia lebbek, Allophyllus africanus, Ficus exasperata, Mallotus oppositifolia and Leea guineensis. The older spoil heaps consist of all these species while the recently deposited spoil heaps are dominated by Elaeis guineensis, Lantana camara and herbaceous species such as Aeschynomene cristala, Calopogonium mucunoides, Ipomea spp and Physalis angulata and grass species such as Andropogon spp and contains sapplings/seedlings of other species at very low frequency.

\section{Worked sites}

The vegetation of most of these sites was dominated by herbaceous species. The vegetation of the ponds created by limestone excavation are dominated by Typha australis while the banks of the ponds are dominated by fern and grass species such as Panicum maximum, Cynodon dactylon, Sorghum bicolor and Andropogon spp.

\section{Unwoked sites}

The vegetation of these sites has been greatly disturbed with farming activities. The present vegetation consists of regrowth woody species interspersed in herbaceous ground layer. Evidence of some of the woody species of the original vegetation is manifested by big stands of Melicia excelsa, Ceiba pentandra, Cola gigantea, Ficus spp left standing during land preparation which dot the terrain. The common regrowth woody species encountered consist of Anthocleista vogelli, Azadiractha indica, Delonix regia, Lecaniodiscus cupanoides, Musanga cecropoides, Psidium 
guajava, Solanum torvum and Spondias mombin. The common woody species encountered along the water courses consist of Alchornea spp and Bambusa vulgaris.

The dominant herbaceous species consist of Chromolaena odorata and Ipomea spp while the common species consist Ageratum conyzoides, Calopogonium mucunoides, Combretum nigerica and Phyllantus amarus and dominant grass species consist Andropogon spp, Panicum maximum, Penisetum purpureum and Sorghum biclor.

\section{Sites outside the factory premises}

The vegetation of these sites had been greatly disturbed by farming activities. It consisted of regrowth woody species interspersed in a ground herbaceous layer. The woody species composition of the regrowth vegetation consists of Azadiractha indica, Cassia siamea, Cleistopholis patens, Cocos nucifera, Cola spp, Morinda lucida, Newbouldia laevis and Trema orientalis.

The grass species were Andropongon spp., Panicum maximum, Penisetum purpureum, Sorghum bicolor while the forb species were Aspilia africana, Ageratum conyzoides, Chromolaena odorata, Euphorbia heterophylla and Phyllantus amarus. Cleistopholis patens were the common plant along the water course. Around the settlement are planted Anarcardium occidentale, Bauhinia monandra, Ceiba pentadra, Citrus species and Elaeis guineensis.

\section{Woody species density and girth sizes}

In the spoil heap sites, Pinus caribaea had the highest density of 528 plants $\mathrm{ha}^{-1}$, followed by Terminalia catapa which had the density of 176 plants ha ${ }^{-1}$ while Albizia lebbeck had the lowest density of of 16 plants $\mathrm{ha}^{-1}$ should be $\mathrm{ha}^{-1}$ (Table 1). In unworked site Anthocleista vogelli had the highest density of 144 plants $\mathrm{ha}^{-1}$ while Bombax buonopozense, Cola gigantea and Ceiba pentandra, had the lowest density of 16 plants $\mathrm{ha}^{-1}$. The unworked sites had the highest mean woody species density followed by the spoil heap sites and the sites outside the factory premises (Table 1). Though the soil heap sites had high plant density, it was made up of individuals contributed by only few species adapted to the sites. The woody species of the sites (within the quarry) had small girth sizes (Table 2) except some woody species of the original vegetation. This indicates that the vegetation is made up of regrowth woody species. Also of note is the lowest plant density of sites outside the factory premises.

\section{Changes in the landform in the quarry site}

The quarrying of limestone deposits has created large man-made ponds whose sizes vary with the extent of quarrying (i.e.depth and area covered) and hills of spoil heap made up of soil, shale and rocks poor in limestone content.These have created new habitats which now support fauna and flora species not found in the other sites in the area.Workers in the factory (personal communication) reported that there are different fish species in these ponds which are now perennial water bodies. Pinus caribaea and Terminalia catapa growing on the spoil heaps were introduced and Typha australis and ferns growing in the ponds were invasive. 
Table 1: Mean density of woody species \pm standard error of the mean in the study plots in Sagamu, Southwestern Nigeria.

\begin{tabular}{|c|c|c|c|c|}
\hline \multirow[t]{2}{*}{ Species } & \multicolumn{4}{|c|}{ Density ha $^{-1}$} \\
\hline & $\begin{array}{l}\text { Spoil } \\
\text { heap }\end{array}$ & Worked site & $\begin{array}{c}\text { Unworked } \\
\text { site }\end{array}$ & $\begin{array}{c}\text { Outside factory } \\
\text { premises }\end{array}$ \\
\hline Albizia adantifolia & - & - & 16 & - \\
\hline Albizia lebbeck & 32 & - & - & - \\
\hline Albizia zygia & 16 & - & 32 & 16 \\
\hline Alchornea cordifolia & - & - & $64 \pm 28$ & 32 \\
\hline Alchornea laxiflora & - & - & $80 \pm 48$ & 32 \\
\hline Allophylus africanus & 16 & & - & - \\
\hline Alstonia boonei & - & - & - & 32 \\
\hline Anacardium occidentale & - & - & - & 32 \\
\hline Anthocleista vogelli & - & - & $144 \pm 48$ & - \\
\hline Azadiractha indica & - & - & $64 \pm 28$ & $48 \pm 32$ \\
\hline Bambusa vulgaris & - & - & $80 \pm 48$ & - \\
\hline Baphia nitida & - & - & 32 & - \\
\hline Bauhinia monandra & - & - & 32 & 32 \\
\hline Brachystegia eurycoma & - & - & 32 & - \\
\hline Canarium schwinfurthii & - & - & - & 32 \\
\hline Cassia siamea & - & - & 32 & $48 \pm 32$ \\
\hline Ceiba pentandra & - & - & 16 & - \\
\hline Cleistopholis patens & - & - & - & $48 \pm 32$ \\
\hline Cola acuminata & - & - & - & $48 \pm 32$ \\
\hline Cola gigantea & - & - & 16 & - \\
\hline Cola nitida & - & - & - & 16 \\
\hline Cocos nucifera & - & - & - & $48 \pm 32$ \\
\hline Delonix regia & - & - & $48 \pm 32$ & - \\
\hline Dialium guineensis & - & - & 16 & 16 \\
\hline Elaeis guinensis & $48 \pm 32$ & - & - & - \\
\hline Ficus capensis & - & - & $48 \pm 32$ & - \\
\hline Ficus exasperata & 16 & - & 16 & - \\
\hline Ficus sur & - & - & $48 \pm 32$ & - \\
\hline Icacina tricantha & - & - & 16 & - \\
\hline Lantana camara & $48 \pm 32$ & - & - & - \\
\hline Lecaniodiscus cupanoides & - & - & $48 \pm 32$ & - \\
\hline Leea guineensis & 16 & - & 16 & - \\
\hline Leucaena leucocephala & - & - & - & 16 \\
\hline Lonchocarpus cynanceus & - & - & 16 & - \\
\hline Ludwigia spp & - & - & 32 & - \\
\hline Mallotus oppositifolia & 32 & - & 16 & - \\
\hline Manihot esculenta & - & - & 32 & - \\
\hline Margaritaria discoides & - & - & - & 32 \\
\hline Milicia excelsa & - & - & 16 & - \\
\hline Morinda lucida & - & - & - & $48 \pm 32$ \\
\hline Musanga cecropoides & - & - & 16 & - \\
\hline Newbouldia laevis & - & - & - & $80 \pm 32$ \\
\hline Pentaclethra macrophylla & - & - & 16 & - \\
\hline Pinus caribaea & $528 \pm 80$ & - & 32 & - \\
\hline Psidium guajava & - & - & $48 \pm 32$ & - \\
\hline Pterocarpus spp & - & - & 32 & - \\
\hline
\end{tabular}




\begin{tabular}{lcccc}
\hline Pycnanthus angolensis & - & - & 32 & 16 \\
Raphia venifera & - & - & 32 & - \\
Rauvolfia vomitoria & - & - & 32 & 16 \\
Ricinodendron heudelotti & - & - & 16 & 16 \\
Securinega virosa & - & - & 16 & - \\
Senna occidentale & - & - & 32 & - \\
Solanum torvum & - & - & $48 \pm 32$ & - \\
Spondias mombin & - & - & $80 \pm 48$ & - \\
Spondiathus preussii & - & - & 16 & - \\
Sterculia tragacantha & - & - & 32 & - \\
Symphonia golubifera & - & - & 16 & - \\
Tephrosia braceolata & - & - & - & 16 \\
Terminalia catapa & $176 \pm 48$ & - & 32 & - \\
Treculia africana & - & - & 16 & - \\
Trema orientalis & - & - & - & $64 \pm 48$ \\
Triumphetta corymbosa & - & - & 32 & - \\
Urena lobata & - & - & 32 & - \\
TOTAL & $928 \pm 56$ & - & $1616 \pm 2.8$ & $784 \pm 5.7$ \\
\hline
\end{tabular}

Table 2: Mean girth size of woody species \pm standard error of mean in the study plots in Sagamu, Nigeria. .

\begin{tabular}{lllll}
\hline \multicolumn{1}{c}{ Species } & \multicolumn{3}{c}{ Mean } & Girth size (cm) \\
\cline { 2 - 5 } & Spoil heap & Worked site & $\begin{array}{l}\text { Unworked } \\
\text { site }\end{array}$ & $\begin{array}{l}\text { Outside factory } \\
\text { premises }\end{array}$ \\
\hline Albizia adantifolia & - & & 31.6 & \\
Albizia lebbeck & $33.5 \pm 3.9$ & - & - & - \\
Albizia zygia & $37.5 \pm 6.4$ & - & $23.7 \pm 2.3$ & $26.5 \pm 7.3$ \\
Alchornea cordifolia & - & - & $4.0 \pm 0.8$ & $4.2 \pm 0.7$ \\
Alchornea laxiflora & - & & $6.3 \pm 1.7$ & $5.8 \pm 2.8$ \\
Allophylus africanus & $18.6 \pm 3.1$ & - & $13.2 \pm 1.6$ & - \\
Alstonia boonei & - & - & - & $28.5 \pm 3.9$ \\
Anacardium occidentale & - & - & - & $38.3 \pm 12.3$ \\
Anthocleista vogelli & - & - & $16.0 \pm 3.7$ & - \\
Azadiractha indica & - & - & $28.0 \pm 7.8$ & $28.5 \pm 2.9$ \\
Bambusa vulgaris & - & - & $16.0 \pm 3.8$ & - \\
Baphia nitida & - & - & $4.2 \pm 0.6$ & - \\
Bauhinia monandra & - & - & $13.6 \pm 2.3$ & $11.8 \pm 5.7$ \\
Brachystegia eurycoma & - & - & $15.3 \pm 4.5$ & - \\
Canarium schwinfurthii & - & - & - & $17.0 \pm 4.8$ \\
Cassia siamea & - & - & $32.5 \pm 8.2$ & $38.0 \pm 13.2$ \\
Ceiba pentandra & - & - & $56.5 \pm 11.3$ & - \\
Cleistopholis patens & - & - & - & $37.4 \pm 12.8$ \\
Cola acuminata & - & - & - & $32.7 \pm 5.9$ \\
Cola gigantea & - & - & $98.7 \pm 18.8$ & - \\
Cola nitida & - & - & - & $16.8 \pm 4.6$ \\
Cocos nucifera & - & - & - & $34.9 \pm 4.3$ \\
Delonix regia & - & - & $36.4 \pm 6.5$ & - \\
Dialium guineensis & - & - & $13.2 \pm 2.7$ & $18.3 \pm 7.3$ \\
Elaeis guinensis & $46.6 \pm 4.2$ & - & $28.8 \pm 2.8$ & - \\
Ficus capensis & - & - & $34.8 \pm 3.9$ & - \\
\hline
\end{tabular}




\begin{tabular}{|c|c|c|c|c|}
\hline Ficus exasperata & $16.5 \pm 2.5$ & - & $48.0 \pm 4.9$ & \\
\hline Ficus sur & - & - & $14.4 \pm 2.8$ & \\
\hline Icacina tricantha & - & - & 8.6 & \\
\hline Lantana camara & $8.3 \pm 1.3$ & - & - & - \\
\hline Lecaniodiscus cupanoides & - & - & $21.2 \pm 8.8$ & - \\
\hline Leea guineensis & $11.2 \pm$ & & 8.7 & \\
\hline Leucaena leucocephala & - & - & - & $12.5 \pm 2.4$ \\
\hline Lonchocarpus cynanceus & - & - & $13.2 \pm 3.6$ & - \\
\hline Ludwigia spp & - & & $9.2 \pm 2.2$ & \\
\hline Mallotus oppositifolia & $12 \pm 2.2$ & & 6.3 & \\
\hline Margaritaria discoides & - & - & - & $32.3 \pm 4.8$ \\
\hline Milicia excelsa & - & & 56.8 & \\
\hline Morinda lucida & - & - & - & $24.8 \pm 3.2$ \\
\hline Musanga cecropoides & - & & $29.8 \pm 4.5$ & \\
\hline Newbouldia laevis & - & - & - & $28.2 \pm 3.9$ \\
\hline Pentaclethra macrophylla & - & - & 14.0 & - \\
\hline Pinus caribaea & $28.5 \pm 8.0$ & - & $16.5 \pm 3.2$ & - \\
\hline Psidium guajava & -- & - & $10.8 \pm 4.9$ & - \\
\hline Pterocarpus spp & - & & $12.3 \pm 1.3$ & - \\
\hline Pycnanthus angolensis & - & - & $25.0 \pm 4.9$ & $23.3 \pm 8.8$ \\
\hline Raphia venifera & - & - & $22.6 \pm 4.5$ & - \\
\hline Rauvolfia vomitoria & - & - & $11.9 \pm 3.7$ & $19.0 \pm 1.4$ \\
\hline Ricinodendron heudelotti & - & & $32.8 \pm 2.8$ & $46.0 \pm 11.2$ \\
\hline Securinega virosa & - & - & $15.7 \pm 5.8$ & - \\
\hline Senna occidentale & - & - & $13.2 \pm 3.7$ & - \\
\hline Solanum torvum & - & - & $9.8 \pm 3.2$ & - \\
\hline Spondias mombin & - & - & $28.0 \pm 4.8$ & - \\
\hline Spondiathus preussii & - & - & 12.7 & - \\
\hline Sterculia tragacantha & - & - & $32.5 \pm 5.5$ & - \\
\hline Symphonia golubifera & - & - & 16.8 & - \\
\hline Tephrosia braceolata & - & - & - & $5.2 \pm 2.2$ \\
\hline Terminalia catapa & $37.6 \pm 4.8$ & - & $32.4 \pm 6.5$ & - \\
\hline Treculia africana & - & - & 19.4 & - \\
\hline Trema orientalis & - & - & - & $18.6 \pm 3.8$ \\
\hline Triumphetta corymbosa & - & - & $13.2 \pm 3.3$ & - \\
\hline Urena lobata & - & - & $8.3 \pm 1.8$ & - \\
\hline
\end{tabular}

\section{DISCUSSION}

Limestone excavation in the area has altered the land form of the area and created new and varied habitats - ponds and spoil heaps. These habitats now support fauna and floral species not found in any other sites in the area. The spoil heaps provide a haven for Pinus caribaea a rare species of the vegetation of the area not found in any other site in the study area. Pinus caribaea and Terminalia catapa are species of wide adaptation and which are normally planted as ornamental trees in the area and also occur in large natural population on the heaps and in other sites indicating their adaptation for the general habitat conditions including the heaps. These plants being fast growing woody species, valuable for the protection of the soil surface from erosion, useful for massive reforestation programme and the conversion of heavily eroded lands on which nothing else could be grown. These plants have been so far successfully used to clothe barren eroded and denuded lands with a tree cover (Lamb and Ntima, 1971; Hayward 1990). These species may be possible candidate species for the revegetation, reclamation and stabilization of quarry sites in cement producing towns of this 
country. The few number of woody species found on the spoil heap vegetation in this study compare to those found on the other locations in the study sites is in agreement with the observations on spoil heap vegetation by Muoghalu (1996) in Nkalagu and Oke and Ibhanesebhor (2010) in Ewekoro. These few woody species are those adapted to the sites. The aquatic habitat provided by ponds created by limestone excavation has also provided refuge for fish species and some plant species including ferns.There is need to assist the natural development of the vegetation of these new habitats (ponds and spoil heaps) which have provided ecologically refuge to rare animal and plant species in the area. Presence of Typha australis and ferns in the pond is an indication of commencement of succession in the area.

The original vegetation of the study area has been completely destroyed by agricultural activities and limestone quarrying. The present vegetation is a regrowth as evidenced by the size of the woody species which are generally small. It is made up mainly of regrowth woody species and some big trees left standing during the land preparation which dot the terrain forming the open upper layer while the herbaceous grass and forb species form the ground cover. The dominant grass species are Panicum maximum, Sorghum bicolor, Andropogon gayanus and forb species are Aeschynomene cristata, Chromolaena odorata, Physalis angulata, and Calopogonium mucunoides. Three distinct vegetation types currently exist in the area; gallery forest along perennial waterbody course, spoil heap vegetation and lowland secondary grassland vegetation, each with distinct species composition.

\section{REFERENCES}

BBRC (Business and Biodiversity Resource Center). 2012. Mining and Quarrying. http://www.businessandbiodiversity.org/ mining.html (accessed 19th March, 2012).
Congdon RA, Herbohn JL. 1993. Ecosystem dynamics of disturbed and undisturbed sites in north Queenland wet tropical rain forest I Floristic composition, climate and soil chemistry. Journal of Tropical Ecology, 9: 349 - 369.

Greig-Smith P. 1983. Qualitative Plant Ecology $\left(3^{\text {rd }}\right.$ edn). Blackwell Scientific Publication: Oxford.

Hayward D. 1990. The phenology and economic potential of Terminalia catappa L. in south-central Ghana. Vegetatio, 90: 125-131.

Hutchinson J, Dalziel JM. 1972. Flora of West Tropical Africa, Keay RWJ, Hepper FN (eds). Crown Agents : London.

Koh LP, Dunn RR, Sodh NS, Colwel RK, Proctor KC, Smith VS. 2004. Species coextinctions and biodiversity crisis. Science, 305: 1632-1634.

Lamb AFA, Ntima OO. 1971. Fast Growing Timber Trees of the Lowland Tropics. $\left(\mathrm{N}^{\circ}\right.$ 6. Pinus caribaea. vol 1). Commonwealth Forestry Institute. University of Oxford.

Muoghalu JI. 1996. The vegetation of a cement manufacturing in Nigeria after 36 years of Limestone Quarrying. Nigerian Journal of Botany, 9: 1-8.

Oke SO, Ibhanesebhor GAO. 2010. Impact of Limestone Quarrying on the vegetation and landform of Ewekoro cement factory site, Ewekoro, in Ewekoro local government area, Ogun State, Nigeria. Nigerian Journal of Botany, 23(2): 361368.

Pickett STA, White PS. 1985. The Ecology of Natural Disturbance and Patch Dyanamics. Acadimic Press: Orlando, Florida.

Pimm SL, Raven P. 2000. Extinction by numbers. Nature, 403: 843-844.

Sousa, WP. 1984. The role of disturbances in natural communities. Annual Review of Ecology and Systematics, 15: 353-391. 